\section{NEW RECREATIONAL CATEGORY ASSOCIATED WITH COMMON WART TRANSMISSION}

\author{
NOVA PRÁTICA RECREATIVA ASSOCIADA À TRANSMISSÃO DE VERRUGAS VULGARES \\ NUEVA PRÁCTICA RECREATIVA ASOCIADA A LA TRANSMISIÓN DE VERRUGAS VULGARES
}

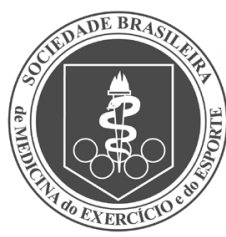

CAse Report

Relato de Caso RePorte de CAso
Felipe Cupertino' (DD (Dermatologist)

Felipe Nazareth de Matos Pinto (ID) de Carvalho

(Dermatologist)

Bernardo Lofiego Caffaro ${ }^{3}$ (ID

(Medical Academic)

1. Universidade Federal do Rio de Janeiro (UFRJ), Rio de Janeiro,

RJ, Brazil.

2. Autonomous researcher, Rio de Janeiro, RJ, Brazil.

3. Universidade Estácio de Sá, Campus Presidente Vargas, Rio de Janeiro, RJ, Brazil.

\section{Correspondence:}

Felipe Cupertino

Rua Real Grandeza, 139, Sala 401, Botafogo, Rio de Janeiro, RJ, Brazil. 22281-033.

cupertinofelipe@gmail.com

\begin{abstract}
Introduction: "Altinha", a variant of beach soccer that is very popular on the beaches of Rio de Janeiro, is a recreational activity that adapts the basics of beach soccer to a game with a circular formation, with the participation of several players who mainly use the following parts of their bodies: feet, legs, head, knees and trunk. Since it is a Brazilian pursuit, the relationship between "altinha" and skin infections is poorly described. The authors report six cases of patients diagnosed with common warts, seeking to correlate the development of these lesions with participation in "altinha". Clinical Case: Six patients, young adults from Rio de Janeiro who play"altinha" on Rio's beaches, with complaints of painless verrucous lesions, were assessed. Physical examination revealed cracked normochromic keratotic papules mainly affecting feet and legs of the dominant limb. In light of the medical history and physical examination, the diagnosis was of vulgar warts. The patients were treated with cryosurgery, obtaining satisfactory results. Discussion: The sport and its outdoor environmental conditions favor transmission of the human papillomavirus due to exposure to factors such as humidity, sweating and trauma, besides direct contact with the infected skin of other players and with colonized surfaces. "Altinha" is played barefoot, and the equipment of choice is the soccer ball, which is constantly shared between players, leading to trauma caused not only by the ball, but also by the sand. Moreover, the activity demands physical exertion from participants, resulting in sweating and potential physical contact. Conclusion: With the increasing popularity of "altinha" among beachgoers, dermatologists must be aware of the sun protection habits of these individuals. They must also be mindful of the need to examine their skin for related dermatosis and to warn them of the risk of infection by the human papillomavirus in this new sport. Level of Evidence IV; Case series.
\end{abstract}

Keywords: Human papilloma virus; Warts; Soccer; Recreation.

\section{RESUMO}

Introdução: A "altinha", variante do futebol de areia, bastante difundida nas praias cariocas, é uma atividade recreativa que adapta fundamentos do futebol de areia à prática em círculo, com a participação de vários jogadores, que usam principalmente os seguintes segmentos: pés, pernas, cabeça, joelhos e tronco. Por ser uma prática brasileira, a relação entre a "altinha" e infecções cutâneas é pouco descrita. Os autores relatam seis casos de pacientes diagnosticados com verruga vulgar, buscando correlacionar o desenvolvimento dessas lesões à prática da "altinha". Caso Clínico: Seis pacientes jovens adultos do Rio de Janeiro e praticantes da "altinha" em praias cariocas, com queixa de lesões verrucosas indolores foram avaliados. Ao exame, apresentavam pápulas normocrômicas, ceratóticas, fissuradas, que acometiam principalmente pés e pernas do membro dominante. Mediante anamnese direcionadae exame físico, o diagnóstico foi verruga vulgar. Os pacientes foram tratados com criocirurgia, e os resultados obtidos foram satisfatórios. Discussão: O esporte e as condições externas da prática esportiva favorecem a transmissão do papilomavírus humano devido à exposição a fatores como umidade, sudorese e trauma, além do contato direto com a pele infectada de outros esportistas e com superficies colonizadas. Os participantes praticam a "altinha" descalçose usam como equipamento uma bola de futebol, que é constantemente compartilhada pelos jogadores, o que leva a trauma tanto com a bola quanto com a areia. Além disso, a atividade exige esforço físico dos participantes, que gera sudorese, e eventual contato físico. Conclusão: Com a prática cada vez mais frequente da "altinha" entre os frequentadores de praias, o dermatologista deve estar atento não só aos hábitos de proteção solar desses indivíduos, como também ao exame da pele em busca de dermatoses relacionadas, assim como alertar para o risco de infecção pelo papilomavírus humano nessa nova modalidade. Nível de Evidência IV; Série de casos.

Descritores: Papiloma vírus humano (HPV); Verrugas; Futebol; Recreação.

\section{RESUMEN}

Introducción: La "altinha", una variante de fútbol playa, muy difundida en las playas del Rio de Janeiro, es una actividad recreativa que adapta los fundamentos del fútbol playa a la práctica en círculo, con la participación de varios jugadores, que utilizan principalmente los siguientes segmentos: pies, piernas, cabeza, rodillas y torso. Como una práctica brasileña, la relación entre "altinha" y las infecciones cutáneas está poco descrita. Los autores relatan seis casos de pacientes diagnosticados con verruga vulgar buscando correlacionar el desarrollo de estas lesiones con la práctica de "altinha". Caso Clínico: Se evaluaron seis pacientes adultos jóvenes de Rio de Janeiro y practicantes de la "altinha" en sus playas, quejándose de lesiones verrugosas indoloras. En el examen, presentaron pápulas 
normocrómicas, queratóticas y fisuradas que afectaron principalmente a los pies y las piernas de la extremidad dominante. En vista de la anamnesis y el examen físico, el diagnóstico fue de verruga vulgar. Los pacientes fueran tratados con criocirugía, y los resultados fueron satisfactorios. Discusión: El deporte y las condiciones externas de la práctica deportiva favorecen la transmisión del virus del papiloma humano en virtud de la exposición a factores como humedad, sudoración y trauma, además del contacto directo con la piel infectada de otros deportistas y con superficies colonizadas. Los jugadores practican la "altinha" descalzos y usan un balón de fútbol como equipo, que es constantemente compartida, lo que resulta en trauma tanto con el balón como con la arena. Asimismo, la actividad requiere esfuerzo fisico de los participantes, lo que genera sudoración y eventual contacto físico. Conclusión: Con la práctica cada vez más frecuente de la "altinha" entre los frecuentadores de las playas, el dermatólogo debe ser consciente no solo de los hábitos de protección solar de estos individuos, sino también de examinar la piel en busca de dermatosis relacionadas, así como alertarlos sobre el riesgo de infección por el virus del papiloma humano en esta nueva modalidad. Nivel de Evidencia IV; Serie de casos.

Descriptores: Papillomaviridae; Verrugas; Fútbol; Recreación.

\section{INTRODUCTION}

Warts correspond to epithelial hyperplasias of the skin and/or mucous membranes caused by different types of human papillomavirus (HPV). The common wart is the most common variant, characterized by firm and asymptomatic keratotic papules. The lesions are usually located on the fingers and back of the hands. When observed on fingers, they mainly affect the peri or subungual regions. ${ }^{1}$

Transmission of the common wart virus can occur directly (autoinoculation) or indirectly through environmental exposure, which can happen on beaches, at sports venues, swimming pools, and other locations. ${ }^{2}$

Physical activity, despite conferring numerous benefits to human health, can cause the development of infectious or inflammatory dermatoses due to direct contact through the skin or with shared materials, and excessive sweating. ${ }^{3,4}$ The impairment of the skin barrier favors the transmission of viral, bacterial and fungal diseases. ${ }^{5}$

Cases of dermatosis transmitted by viruses, such as herpes simplex, molluscum contagiosum and the common wart, have been reported in different groups of athletes. ${ }^{3}$

In Brazil, beach soccer is a physical activity that has become widespread, especially in the last decade. ${ }^{6}$ In Rio de Janeiro, a variant of beach soccer called "altinha" has become very popular. This recreational activity adapts the basics of beach soccer to a game with a circular formation, with the participation of an indeterminate number of players, whose objective is to keep the ball in the air. Thus, to maintain control over this movement for as long as possible, players mainly use the following parts of their bodies: feet, head, legs (pretibial region), knees, thighs and chest.

The trauma produced by the impact of the ball with the feet and of the feet with the ground, as well as occasional direct contact between players, can produce traumatic lesions on the feet, such as nail dystrophies, calluses and blisters, as well as viral infections or other dermatoses.?

The authors report six cases of patients diagnosed with common warts, seeking to correlate the development of these lesions with the recreational pursuit of "altinha" on Rio's beaches.

\section{CASE REPORT}

Six patients, three female and three male, young adults (average age 24 years), living in neighborhoods on the south side of the city of Rio de Janeiro and playing "altinha" in the same place, Ipanema beach (Table 1). These patients complained of painless verrucous skin lesions located on the lower limbs. Dermatological examination revealed normochromic keratotic papules, smaller than one centimeter in diameter, with cracks on the surface, which mainly affected the feet and legs of dominant limbs (Figures 1 and 2). Examination with a dermatoscope, an auxiliary device with 10x magnification, showed red-violet globules surrounded by a white halo, compatible with the common wart (Figure 3). In light of the targeted medical history and physical examination, a clinical diagnosis of common warts was made. The treatment of choice was cryosurgery due to its good response and tolerability and short recovery time. Patients were treated with one to three monthly sessions, achieving clinical cure (disappearance of the lesions).

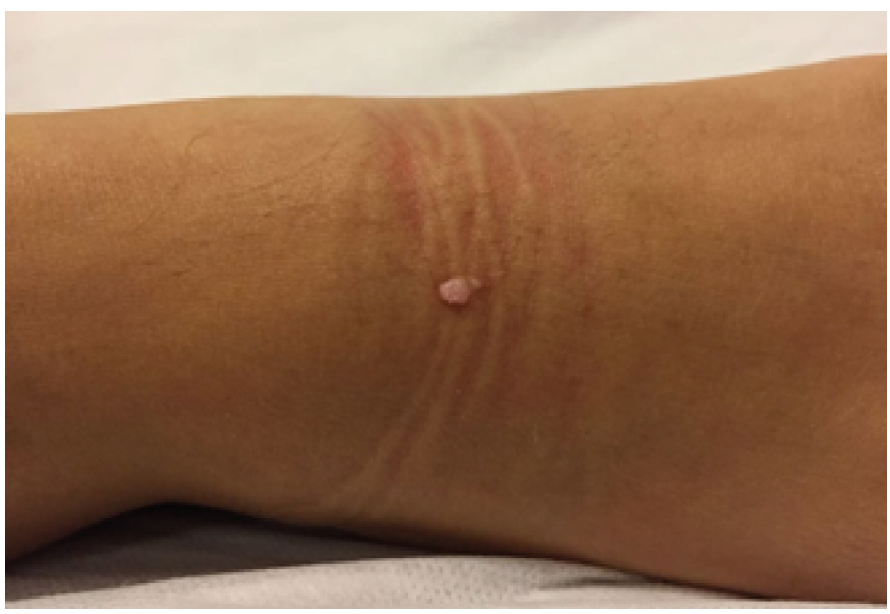

Figure 1. Common wart, normochromic keratotic papule with cracks on the surface, located on the back of the foot.

Table 1. List of patients according to sex, age, site of transmission, location of the lesions and therapeutic management.

\begin{tabular}{|c|c|c|c|c|c|c|}
\hline Patient & Sex & Age & Beach & $\begin{array}{l}\text { Monthly frequency of } \\
\text { "altinha" participation }\end{array}$ & Site and number of lesions & $\begin{array}{c}\text { Treatment and } \\
\text { number of sessions }\end{array}$ \\
\hline Patient 1 & Female & 25 years & Ipanema & 8 days/month & Right foot (1) and right leg (3) & Cryosurgery (1) \\
\hline Patient 2 & Male & 26 years & Ipanema & 4 days/month & Right foot (1) and right leg (3) & Cryosurgery (1) \\
\hline Patient 3 & Male & 22 years & Ipanema & 15 days/month & Right leg (1) & Cryosurgery (3) \\
\hline Patient 4 & Male & 24 years & Ipanema & 12 days/month & Left leg (1) & Cryosurgery (1) \\
\hline Patient 5 & Female & 24 years & Ipanema & 10 days/month & Right foot (6) & Cryosurgery (2) \\
\hline Patient 6 & Female & 24 years & Ipanema & 14 days/month & Right leg (4) & Cryosurgery (2) \\
\hline
\end{tabular}




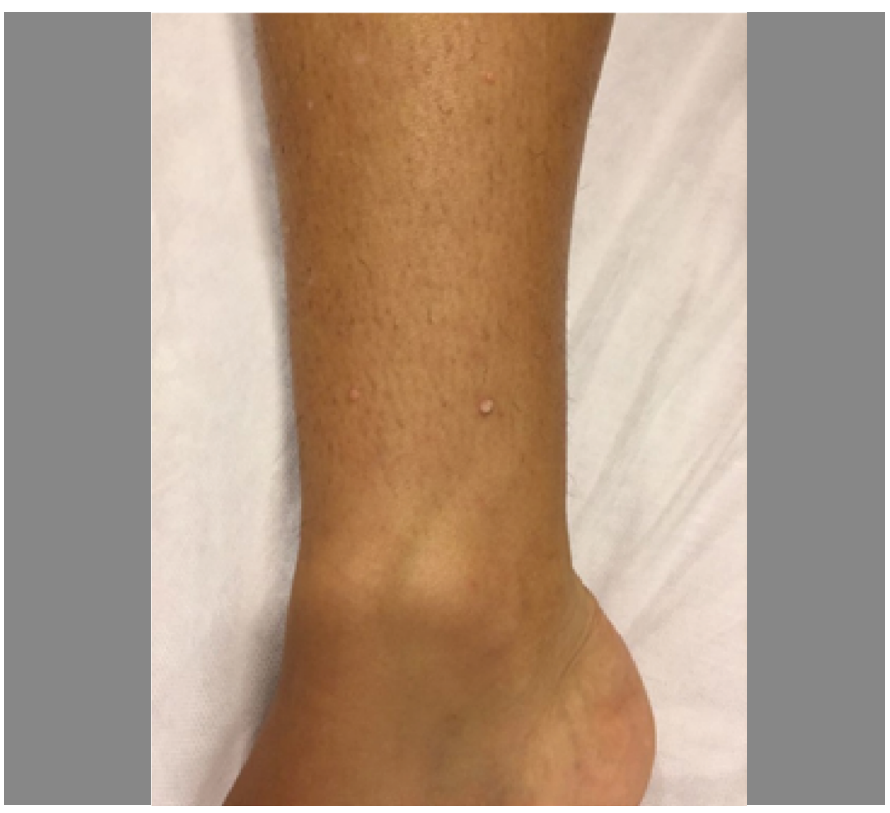

Figure 2. Common warts located in an area of trauma with a soccer ball.

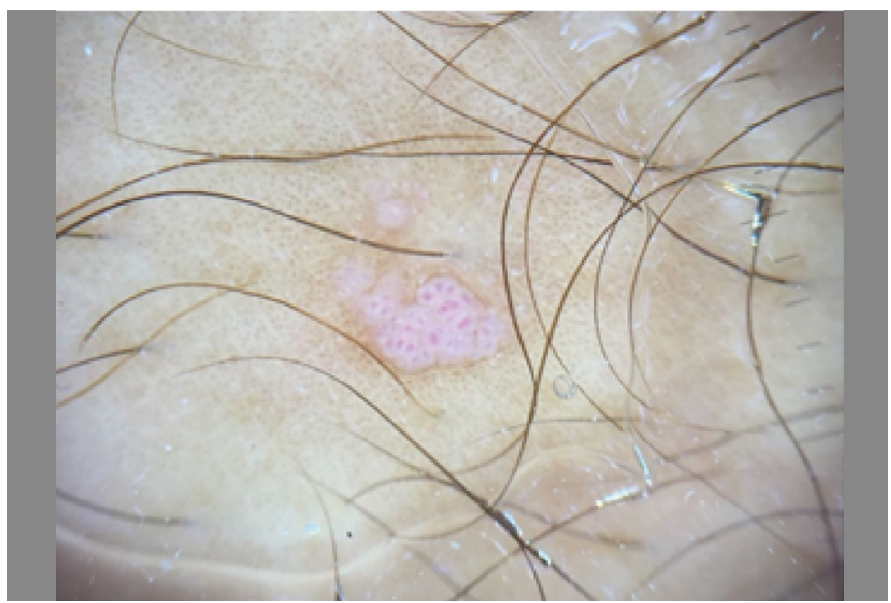

Figure 3. Dermoscopy (10x magnification): reddish globules surrounded by white halo.

\section{DISCUSSION}

Up until the 19th century, cutaneous warts were considered a clinical manifestation of syphilis or gonorrhea. After the identification of its viral etiology, the cause of the disease was attributed to a single virus, the Human Papillomavirus (HPV). ${ }^{8}$ One of the most distinctive features of the papillomavirus group is its host-specific genotypic restriction, and the preference of certain types of papillomavirus for different anatomical sites. ${ }^{2}$ With technological advances, it has been possible to identify at least 150 genotypes of the HPV virus. ${ }^{9}$ The common wart is more closely associated with HPV types 1, 2, 4, 7, 27 and 57.

Lesions are characterized by firm papules with a keratosic surface, which may have cracks and appear in a variable number, dispersed or grouped. The Koebner phenomenon, despite being a more common finding in cases of flat warts, may be present at trauma sites. ${ }^{9}$ This isomorphic reaction corresponds to the appearance of new warts after an external aggression, such as burns, scratches, and friction. It is usually limited to the topography of the trauma. ${ }^{10}$ The location and virulence of lesions, as well as the immunocompetence of the exposed individual, are factors that influence transmission. ${ }^{8}$

Participation in sports, even if recreational, can generate infectious skin lesions as a result of physical contact between participants, inadequate cleaning of equipment, and trauma/external environmental conditions. ${ }^{3}$ Bacterial, fungal and viral agents are primarily responsible for skin infections that affect team sports participants, and can result in individual morbidity and team disorganization, since although warts are characteristically asymptomatic, they can be a source of personal discomfort. ${ }^{11}$

Individuals who participate in collective physical activities are more susceptible to skin and skin structure infections due to exposure to factors such as humidity, sweating, trauma and friction, in addition to direct contact with the infected skin of other participants, with colonized surfaces (pools, showers and changing rooms), and the use of occlusive equipment that damages the stratum corneum, creating a gateway. ${ }^{12,13}$ Moisture dilates the pores, facilitating the penetration of the HPV. As it is a self-inoculating disease, it can spread to other skin sites. ${ }^{11}$

There are several ways of treating warts, including surgical techniques such as curettage followed by electrocoagulation, chemical cauterization with the use of acids, or the application of liquid nitrogen. ${ }^{9}$ However, these procedures can keep the individual from engaging in physical activities for a long time. Therapy with the topical immunomodulator Imiquimod has proven advantageous, since the treatment is painless and non-ablative, allowing patients to resume their activities more quickly. ${ }^{11}$

A study of swimmers, handball and soccer athletes in Turkey showed a higher prevalence of common warts in swimmers, followed by handball and soccer players. In the swimmers, the places most affected by viral dermatoses, including common warts, were the trunk and feet, in that order. In soccer athletes, the feet correspond to the most affected area, particularly the periungual region. ${ }^{14}$

The sport known as "altinha", a variant of beach soccer that associates leisure with physical exercise, is very popular on the beaches of Rio de Janeiro, is played outdoors and usually close to the sea, so that players are exposed to environmental conditions such as heat and humidity most of the time. Participants play "altinha" barefoot and use a soccer ball, which is shared constantly, resulting in trauma from both the ball and the sand. They aim to keep the ball in the air and employ varied bodily movements to accomplish this goal, which can cause not only traumatic musculoskeletal injuries, but also damage to the surface of the skin. Moreover, the activity demands physical exertion from the participants, generating sweating and occasional physical contact between them.

Common warts that affect the "altinha" participants in this study can be found on the legs and feet of dominant limbs, which are exercised constantly during the activity. These body segments are more exposed to trauma and direct contact with the soccer ball. In fact, the patients did not develop further lesions after switching the ball used during the game. As preventive proposals, we suggest restricting physical contact during the activity, limiting the number of participants, wearing shoes to protect the feet (a segment that has greater contact with the ball), and cleaning the ball and the parts of the body most exposed at the end of the activity. It is essential to make sure that a player with lesions suggestive of common warts temporarily suspends his or her participation.

A wide range of young male and female participants are recruited to play "Altinha". Female participants represent a large portion of those interested in the activity. Among the cases recorded in this series, half of the patients were women. When questioned, participants in this study also reported that other players had similar injuries, which is why more comprehensive clinical trials should be encouraged.

\section{CONCLUSIONS}

With the increasing popularity of "altinha" among beachgoers, especially adolescents and young male adults, dermatologists must be aware of the sun protection habits of these individuals. They must also be mindful of the need to examine their skin for dermatoses related to physical activity, and to warn them of the risk of contagion by common warts.

All authors declare no potential conflict of interest related to this article 
AUTHORS' CONTRIBUTIONS: Each author made significant individual contributions to this manuscript. FC: patient selection, intellectual concept, writing, review; FNMPC: patient selection and intellectual concept; BLC: data analysis, writing and review. All authors approved the final version of the manuscript.

\section{REFERENCES}

1. Breznik V, Komlos KF, Hošnjak L, Luzar B, Kavalar R, Miljković J, et al. Determination of causative human papillomavirus type in tissue specimens of common warts based on estimated viral loads. Front Cell Infect Microbiol. 2020;10:4.

2. Al-Awadhi R, Al-Mutairi N, Chehadeh W. Prevalence of HPV Genotypes in adult male patients with cutaneous warts: a cross-sectional study. Med Princ Pract. 2019.

3. Carr PC, Cropley TG. Sports dermatology: skin disease in athletes. clin Sports Med. 2019;38(4):597-618.

4. Pleacher MD, Dexeter WW. Cutaneous fungal and viral infections in athletes. Clin Sports Med. 2007;26(3):397-411.

5. Decker CF. Skin and soft tissue infections in the athlete. Dis Mon. 2010;56(7):414-21.

6. Fazolo E, Cardoso PG, TucheW, Menezes IC, Teixeira ME, Portal MN, et al. A dermatoglifia e a somatotipologia no alto rendimento do beach soccer - seleção brasileira. Rev Educ Física. 2005;130:45-51.
7. Purim KS, Niehues LP, Teles Filho FQ, Leite N. Aspectos epidemiológicos das micoses dos pés em um time chinês de futebol. Rev Bras Med Esporte. 2006;12(1):16-20

8. De Villiers EM. Heterogeneity of the human papillomavirus group. J Virol. 1989;63(11):4898-903.

9. Leung L. Treating common warts - options and evidence. Aust Fam Physician. 2010;39(12):933-7.

10. Boyd AS, Neldner KH. The isomorphic response of Koebner. Int J Dermatol. 1990;29(6):401-10.

11. Adams BB. Dermatologic disorders in athletes. Sports Med. 2002;32(5):309-21.

12. Adams BB. Sports dermatology. Dermatol Nurs. 2001;13:347-63.

13. Jiménez-Diaz JF, Romero Guillén J, Trigueros Carrero JA. Prevalência de doenças infecciosas no esporte. Rev Bras Med Esporte. 2000;6(1):23-8.

14. Derya A, llgen E, Metin E. Characteristics of sports-related dermatoses for different types of sports: a cross-sectional study. J Dermatol. 2005;32(8):620-5. 